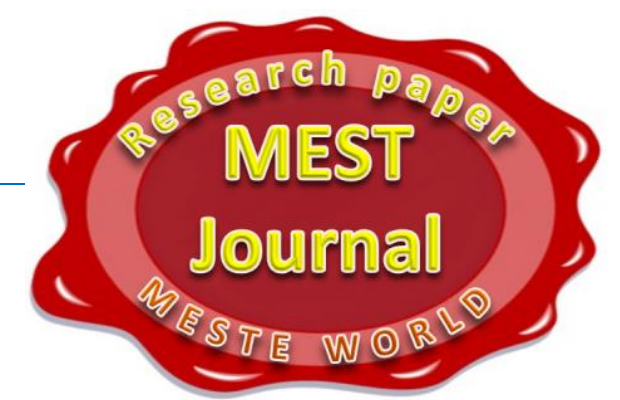

\title{
THE EUROPEAN COUNCIL AND THE COUNCIL OF THE EU - PAST, PRESENT AND FUTURE
}

\author{
David Ramiro Troitino \\ Tallinn University of Technology, Tallinn, Estonia
}

\section{(C) MESTE NGO}

\author{
JEL category: F, F01, F15
}

\begin{abstract}
The European Council and the Council of the European Union are two of the main institutions of the European Union. The first holds the political powers of the organization, being fundamental in its development and deeper integration as all the Treaties need its approval. The second, the Council of the European Union is the main actor in the European Union, as its role inside the organization is the most influential. Both organizations represent the member states, and traditionally have been a stronghold of the intergovernmental side of the EU. Currently both still play a crucial role in the organization, but they are losing ground to other institutions based on federalism or neofunctionalism, like the European Parliament or the European Commission. The future of the Council will mark the future of the Union, and hence it is primordial to reform the institutions to face the new challenges of the XXI century.
\end{abstract}

Keywords: European Council, Council of the European Union, European integration, future government of Europe, European institutions, European key actors, decision making in the European Union

\section{INTRODUCTION}

There are two institutions representing the member states in the Union, the European Council, where the political heads of the member states are embodied, and the Council of the European Union, where the national ministers in charge of different areas sit together. Obviously, the first institution is more powerful because it is where the Prime Ministers and Presidents meet,

The address of the author:

\section{David Ramiro Troitino}

玤" perdices57@yahoo.es and they are the heads of the national governments, and the ministers normally follow the commands of their governments, but in the working system of the Union the Council of the EU holds, at least nominally, most of the power. (Tsoukalis, 2008)

On the other hand we have a third institution called Council of Europe linked with human rights protections that has nothing to do with the EU. It is an international organization born in Europe but that currently includes many nations of Asia, but its name leads to confusion to who is who in the European Union and in these three institutions. 


\section{THE EUROPEAN COUNCIL}

Since the creation of the first European Communities, there have been meetings of the heads of governments of the member states to negotiate and develop European integration. At first, these meetings were informal reunions outside the framework of the European institutions, and hence out of the control of the European Communities. It was a faster way to take decisions, without any voting system, just by unanimous agreements. Nevertheless, it was during the presidency of de Gaulle when these meetings became more official, in an attempt to dwarf the European institutions and give a more international character to European integration according to the ideas of the French Premier. De Gaulle pretended to outline the intergovernmental character of the European Communities, and the best way was promoting to the top of the Communitarian pyramid the more intergovernmental option, the European Council, even when it was not still an institution belonging to the organization.

Another French president, Giscard d'Estaing, formalized the meetings of the political leaders of the national governments of the member states of the Communities, and in 1975 the first official meeting was held in Dublin in order to give a political push to the integration in Europe. (CostaFont, 2012) Nevertheless, the institution was not included in the Union until the Treaty of the Single European Act in the '80s and the Treaty of Maastricht entailed the role of the institution in the Union. Finally, the status of this European institution was included in the Treaty of Lisbon, formally separating the European Council from the Council of the European Union. Nevertheless, it has been the leading force in the Union since the first Community until the present, even if it was not an official institution. The main change with this recognition is related to the voting system, before consensus, and after the Treaty of Lisbon some decisions can be taken by qualified majority, giving more power to supranational Europe and reducing slightly the intergovernmental character of this institution. (Anon, The institution, 2013)

\subsection{The power of the European Council}

The European Council is the political leader of the Union, and hence it is its main power leading the European integration. It acts as a forum where the member states meet and discuss the next step in integration, the next policy to be included in the treaties, and the further development of existing policies. As the member states hold sovereignty in all national policies outside the Union, they are the ones to decide about sharing the powers given to them by their own citizens with the other members of the organization. The Council will analyze the benefits and the losses of sharing new policies in the context of the Union, and hence push for deeper integration in the fields where they think it is needed. The decisions in the European Council are taken by consensus, and in some cases can be taken by unanimity or qualified majority if the treaties of the Union allow it. The main difference between unanimity and consensus is that in the first there is voting where all the votes have to be positive, and in the second just informal discussion until all the member states agree on any issue.

The development of any new policy in the Union starts in the European Council by consensus; once it is established, the voting system is unanimity until the member states assure that the new policy is working properly; and, afterwards, the European Council passes the decision making to the other European institutions and opens the possibility of a qualified majority voting system. So, the European Council can be considered the motor of the Union, the leading force in terms of deepening integration.

As it is composed of the executive powers of the member states, it has a big influence on different policies of the Union, especially the Common Foreign and Security Policy. It also has some executive power in the Union, appointing some key persons in the Union, such as its own president, the president of the European Commission, the person in charge of the Common Foreign and Security Policy, and the president of the European Central Bank. The influence of the European Council over the Council of the European Union provides it with an important influence over the legislative process in 
the Union, even though it is an informal power. (Elgström, 2004)

\subsection{Composition}

The European Council consists of the heads of state or government of the member states, plus its own president and the president of the European Commission. The latter can attend meetings but cannot take part in voting. His role is mainly to keep in touch with the member states and inform them about the situation of the Union from a European perspective, often different from national opinions. The European Council meets twice every six months, normally in Brussels, convened by its President, but in case of any urgent matter it can have special meetings. Usually in the meetings each state has two representatives, the head of the state or the head of the government, and a national minister if needed. The President of the Commission can also attend the meetings with another member of the Commission.

The president of the European Council chairs the meetings and drives forward its work. He ensures the preparation and continuity of the work of the European Council in cooperation with the President of the Commission, and on the basis of the work of the General Affairs Council. He also endeavors to facilitate cohesion and consensus within the European Council and presents a report to the European Parliament after each of the meetings of the European Council. Moreover he, at his level and in that capacity, ensures the external representation of the Union on issues concerning its Common Foreign and Security Policy, without prejudice to the powers of the High Representative of the Union for Foreign Affairs and Security Policy. (President of the European Council, 2009) The European Council elects it's President by a qualified majority for a term of two and a half years, renewable once. He must report to the European Parliament after each European Council meeting, being a link between both European institutions. (Staab, 2013)

The Secretary-General of the Council can also attend the meetings on most occasions, and normally is a key figure in the meetings, because he is a person who has been attending the meetings of the Council for a long period of time, and his expertise and the experience accumulated by the officials working for him are used to solve conflicts within the European Council. The Secretariat-General of the Council is a body of civil servants constituted to help in the meetings of the European Council, and is divided into different areas, including the most important policies of the Union, such as agriculture or environment. It also has a legal department to give legal advice to the European Council and a private office for internal affairs. (Anon, Hierarchic view, n.d.)

All the heads of state also have different teams made up of national experts, normally national civil servants, who are not members of the European Council staff but play a significant role in the preparation of meetings, discussing with their counterparts and providing information needed to the members of the European Council for their meetings.

\subsection{Future}

The European Council has been often criticized because of its obscure working system, where most of the decisions are made in private meetings between the member states rather than in the negotiation room. This makes it difficult to understand how and why decisions are taken. Also, the alignment between France and Germany has determined traditionally the direction of European integration, even when currently the relation between Merkel and Hollande is not precisely harmonious. Traditionally if both countries arrived to any meeting of the European Council with a common position adopted prior to the summit, the other countries had much less opportunity to influence the process, and hence the bilateral meetings between France and Germany have been seen as a way of keeping the influence of both states over the Union.

The election of the first president of the European Council pretended to give one face to Europe, ending the rotation system where each member state held the presidency for six months. It was done because with a Union of almost 30 members, each member state would have held the presidency each 15 years, a long period of 
time and unpractical in terms of efficiency. Nevertheless, there was a big debate about the personality of the new president, whether it should be a strong and influential personality or a grey and docile personality. This discussion was a link with the power of the new position and its relation with the rest of the members of the European Council. As Herman Van Rompuy, from Belgium, was elected, the European Council made it clear that it did not need any leading force besides the member states, and the role of the president is more one of an intermediary between the different positions of the member states than a leading force within the European Council. The problem here is that the president represents the Union internationally, and if his position inside the European Council is weak, he is going to have a low profile in the international arena, weakening the positions of the European Union in world affairs. So it is necessary to give more importance to the presidency in order to secure his international respectability. The future of this organization pass for the fully comunitarization of it spreading the qualified majority voting system and abandoning the unanimity. It will make the organization the real holder of the European sovereignty and the most important institution of the EU, and of the possible future government of Europe as a political body able to decide the major priorities of the Union and control its government acting as a counterbalance to the power of the European Parliament.

\section{THE COUNCIL OF THE EUROPEAN UNION}

This is one of the most important institutions in the European Union because it is the representative of the member states in the working system of the Union, more involved in practical matters than the European Council, and with an almost omnipresence in the Union. At the beginning of European integration, in the ECSC the Council existed but its power was more limited, with a High Authority being the dominant institution. Nevertheless, the Treaty of Rome established a Council with more power in order to secure the control of the Union and the process of integration to the member states. After the creation of the European Economic Community the Council became the most powerful institution of the Union, and the key force in the legislative process.

The Council is composed of national ministers, one from each member state. The internal composition depends on the topic discussed, for example if it is agriculture, the 28 national ministers of agriculture go to the meeting; if it is environment, the 28 national ministers in charge of environment in their respective countries go the meeting. In general meetings normally include the foreign affairs ministers of the member states. The Council also has a rotating presidency of six months among the member states according to an established order. It plays a vital part in the organization of the work of the institution, notably as the driving force in the legislative and political decision-making process. (Levitt \& Lord, 2000) The president has to organize and chair all meetings and work out compromises capable of resolving difficulties. Mainly he decides the agenda and what the Council is going to discuss.

The decision making in the Council is mainly qualified majority, with some cases where unanimity is required, mainly in the fields where the member states have an important national interest, as Spain with the Cohesion Funds, or France and Germany with the free movement of workers. Nevertheless, the qualified majority is mainly used as a tool to reach a consensus within the Council, because most of the decisions are taken after an agreement among the representatives of the member states. (Glenn \& Gordon, 2007)

The qualified majority was an exception at the beginning of European integration in the Council, when unanimity was the common rule, but after each treaty the majority system was spread to the decision making and became the main procedure in the Council little by little. It shows the cautious approach of the Union to this voting system because it means sharing sovereignty among the member states, when one member state can be outvoted and forced to accept a decision of the majority against their national interest, just because it is better for the whole Union. (Kant, 2005) Normally new policies of the Union are decided by unanimity, and once the 
main problems have been solved and the member states feel secure and sure about the right working of the policy in the European Union, the voting system can change to qualified majority. (Europa, 2007) It has been a pattern of integration in the whole history of the Union: first the member states want to keep control over newly integrated policies, and afterwards, when the policy is already working well and without major problems, the states transfer control of the policy to the European institutions, mainly the Council and the European Parliament.

Rotating presidency of the Council

\begin{tabular}{|l|l|l|}
\hline 2014 & First half-year & Greece \\
\cline { 2 - 3 } & Second half-year & Italy \\
\hline 2013 & First half-year & Ireland \\
\cline { 2 - 3 } & Second half-year & Lithuania \\
\hline 2012 & First half-year & Denmark \\
\cline { 2 - 3 } & Second half-year & Cyprus \\
\hline 2011 & First half-year & Hungary \\
\cline { 2 - 3 } & Second half-year & Poland \\
\hline 2010 & First half-year & Spain \\
\cline { 2 - 3 } & Second half-year & Belgium \\
\hline 2009 & First half-year & Czech Republic \\
\cline { 2 - 3 } & Second half-year & Sweden \\
\hline
\end{tabular}

Source: (Anon, Presidency websites, 2013)

Distribution of votes for each Member State in the Council of the EU

\begin{tabular}{|l|r|}
\hline $\begin{array}{l}\text { Germany, France, Italy, United } \\
\text { Kingdom }\end{array}$ & 29 \\
\hline Spain, Poland & 27 \\
\hline Romania & 14 \\
\hline Netherlands & 13 \\
\hline $\begin{array}{l}\text { Belgium, Czech Republic, Greece, } \\
\text { Hungary, Portugal }\end{array}$ & 12 \\
\hline Austria, Bulgaria, Sweden & 10 \\
\hline $\begin{array}{l}\text { Denmark, Ireland, Lithuania, Slovakia, } \\
\text { Finland }\end{array}$ & 7 \\
\hline $\begin{array}{l}\text { Cyprus, Estonia, Latvia, Luxembourg, } \\
\text { Slovenia }\end{array}$ & 4 \\
\hline Malta & 3 \\
\hline TOTAL & 345 \\
\hline
\end{tabular}

Source: (Anon, Council, n.d.)
The qualified majority has had many different shapes since the Treaty of Rome in the ' 50 s, and currently under the Treaty of Lisbon there is a weighting of the votes that each member state holds, plus a system of double majority. The distribution of the votes for each member state depends on different matters, as population or economic power, but in contrast with the EP, there is equality between the main countries of the Union, Germany, France, Italy and the United Kingdom. Basically the unwritten rule of equality between France and Germany, as the motor of the Union, has been respected here. The maximum number of votes for each member state was established at 29 , and hence no state will have more than this amount. Also, member states have to cast their votes in bloc. It means that a member state may not split its votes and hence, the number of votes rather describes the weight of a member's single vote.

The double majority system is based on the majority of the votes in the Council plus:

1. A majority of the member states. If the proposal comes from the European Commission, a minimum of $55 \%$ of the member states is required. If the proposal comes by a different path, the percentage increases to $72 \%$ of the member states. This is clearly a measure to protect the medium and smaller member states that could be outvoted by an alliance of the big countries, and hence forced to accept something against their will. If the proposal comes from the Commission, it means it comes from an institution whose interest is Europe and has no major influence from the member states, and hence the majority percentage of the states is not as high as if the proposal comes from a member state, for example.

2. A majority of the European population. If some member states representing at least $62 \%$ of the European population are against any proposal, even if the proposal has been back by the majority of the Council, the measure will not be adopted. It is an action to protect the big countries from being outvoted in the Union, and avoiding a situation where the majority of the member states representing a minority of the 
European population could decide the future of the Union. (EU, 2007)

In addition to these main conditions, there are minority block systems, where the power of the big member states is bigger. Nevertheless, as has been said before, the normal procedure of the Council is based on agreements and consensus among the member states, and the voting system is basically used to force the consensus or, in exceptional cases, when a member state does not want to reach an agreement. For example in 2008, 128 out of 147 Council decisions were unanimous. (Ramiro Troitino, 2013)

\subsection{Working system in the Council}

The Council depends mainly on the work of the national civil servants to get the information needed to adopt decisions. At the beginning of the process, the member states meet in different working groups for an early discussion. The working groups are formed by national civil servants who are specialists on the topic being discussed; for example, in justice, high ranking national civil servants of the national ministries of Justice will meet in accordance with the sphere of their work. (Anon, Working groups of the Council of the European Union, 2008) The working groups discuss mainly the proposals of the European Commission, but they can also meet if the Council requires it because of other reasons. Mainly the work at this level is more technical, and the different representatives from each member state give their opinions and work together in order to achieve a common position. They make reports when the working groups agree on any issue or find problems to discuss further. In any case, they pass their report to the COREPER, or committee of permanent representatives. If the working group agrees on a common position, normally the COREPER just agrees on it also, but if the working groups find any problem, further discussion will be done in the COREPER.

This early stage of the discussion is very important because it influences further agreements and discussion within the Council, and here is where the influence of the bigger states can be felt more, because normally the bigger states have more civil servants and experts than smaller states, and hence can influence the discussion more. It is obvious that the capacity of a country like Germany in terms of experts and civil servants is much higher than the capacity of a state like Malta, where there are not experts in all the fields discussed in the Council and their expertise is normally lower.

The COREPER is the permanent representative of the member states in the European Union; the main mission of the COREPER is to prepare the agenda of the meetings of the Council and oversee and coordinate the work of the working groups. It is divided into two main committees, COREPER I, where the deputy heads of the national missions meet to discuss mainly social and economic issues, employment, social policy, health and consumer affairs, competitiveness, transport, telecommunications and energy, agriculture and fisheries, environment and education, and youth and culture. COREPER II is where the heads of the national missions with the rank of ambassadors meet to discuss mainly political issues, but it also includes financial and foreign policy issues.

The COREPER obtains the information from the working groups and normally takes decisions without debate if there was already agreement in the working groups. If the working groups send a report to the COREPER where some problems were not solved, the COREPER holds debate and tries to reach agreement. After the COREPER makes its own reports on the issues discussed, it sends them to the Council for the ministers to approve them or for further discussion at a higher level. It makes three different proposals for the agenda of the Council:

1. I. Points: Information for the ministers that does not need any decision.

2. A. Points: These are the proposals where an agreement has been reached in the COREPER and there is no necessity of further debate in the Council, and normally the Council just approves them.

3. B. Points: No agreement has been reached in the COREPER and the issue is sent to the Council for further discussion. The Council will negotiate until they reach an 
agreement. Normally these are sensitive issues for some member states, important for their national interest, where they try to get the best conditions for their respective states.

The Council in its highest expression, the meetings of the ministers, normally deals just with a few problematic but important issues, because normally there has been agreement in the working groups or in the COREPER, and hence the Council can focus on the most important proposals for their own states, mostly in a political sphere. (Anon, Hierarchic view, n.d.)

\subsection{Secretary of the Council}

This is a service from the Union to assist different European institutions, as the Council of the European Union, the Council Presidency, the European Council, and the President of the European Council. It is composed of around 3,500 civil servants, and comprises a legal service, eight directorates-general, and a private office split between departments answering directly to the Secretary-General of the Council and the High Representative for the CFSP and departments answering to the Deputy SecretaryGeneral. (Anon, The High Representative of the Union for Foreign Affairs and Security Policy, 2009) Since the Treaty of Lisbon the Council decides on the organization of the General Secretariat by a simple majority. (Grahn, 2009) Its main tasks are:

- Organize and coordinate Council work

- Legal advice

- Political advice to the presidency

The person holding the General Secretariat is an important part of the Council because it has had presence in the meetings for a long period of time, far from the temporal assistance of the national ministers that depends on the national elections, and hence can provide a wider perspective in discussions in order to unblock the complicated debates. It also can advise the ministers in solving different situations using the experience gained in previous discussions, giving examples to the Council about similar problems in the past and how these situations were solved.

\subsection{Council headquarters}

The Council is in a situation similar to that of the European Parliament, with different locations as the consequence of the previous Communities and European treaties, but its main seat is located in Brussels. Most of the services of the Council, as well as the General Secretariat, are also located in Brussels. Nevertheless, as the Council of the ECSC was located in Luxembourg, it was decided that the meetings of the Council during the months of April, June, and October are to be held in Luxembourg. The location of Brussels was decided upon after the merger of the existing communities because the European Commission and some parts of the European Parliament were located in Belgium, and hence communication between the European institutions would be easier if they were located in the same place. This logical decision was denied to the European Parliament, which still has some offices in Luxembourg. The Council extraordinary can also have its meetings in its higher form in other cities, but only under extraordinary circumstances.

\subsection{The power of the Council}

The Council acts mainly in three fields: Foreign Affairs, where it is the central institution, Legislative Procedure, and Budgetary Authority, where it shares control with the European Parliament. (Rodríguez-Pose, 2002)

The role of the Council in foreign affairs is crucial, and it is the major European institution in this field. (Ahearne, Pisani-Ferry, Sapir, \& Véron, 2006) The decisions here are mainly taken by consensus or unanimity, because the external interests of the member states are different and often a common agreement is very difficult. Anyway, the decision to adopt any measure related to the CFSP is taken in the Council. It also has a High Representative of the Union for Foreign Affairs and Security Policy. This post combines three functions: the EU's representative for the CFSP, the President of the Foreign Affairs Council, and a Vice-President of the Commission. At the moment, this post is held by Catherine Ashton. (Anon, The Common Foreign and Security Policy (CFSP), n.d.) Her designation was controversial because she is a 
low profile politician with no political stature. It means tighter control by the Council over this newly created position. If the Council would have wanted a strong CFSP, a strong position in the external world, it would have chosen a candidate with more experience and greater initiative.

The legislative power of the Council is mainly shared with the European Parliament via the codecision system, where both institutions need to agree in order to adopt new legislation for the Union, and this works in most of the European policies. Anyway, there are some areas with different procedures where the Council holds the responsibility for approving new legislation. Mainly these are areas where the member states are afraid of losing control, as justice and home affairs or fiscal aspects of other policies. Here the Council decides about the new legislation according to its internal rules. Both procedures make the adoption of new legislation in the European Union impossible without the consent of the Council, and hence without the consent of the member states, making the Council a central institution in the context of European integration. (McKay, 1999)

The budgetary authority of the Council is also very important, but has decreased over the years. Previously, the Council had control over the most important chapter of the budget, the money dedicated for the obligations of the Union, and it shared budgetary power with the Parliament in the rest of the chapters, but these limitations have been erased and now the Council and the Parliament stand equally in negotiations for the EU budget. (Pisani-Ferry, 2005) If both institutions are not able to reach agreement, there is a conciliation committee where this can be discussed further. It works in a way similar to the co-decision system. In addition to the budget, the Council coordinates the economic policy of the member states of the Union. (Crafts, 2008)

\subsection{Future}

The Council of the EU is losing ground to other institutions inside the European Union, but still is clearly the most important institution in terms on political power and decision making. From one side, the political power is moving away to the
European Council, the representation of the heads of the member states. It is a natural consequence of the most active role of the European Council in the European Union affairs. The clearly definition of the functions of the European Council in the Treaty of Lisbon has decrease the power of the Council of the EU. Nevertheless it is a logic movement that more political power is in the hands of the Head of the member states, as they represent the national governments elected in national elections, and hence they hold the national sovereignty and have the capacity to share this sovereignty in the European level.

On the other side, the European Parliament is becoming more important in the decision making of the European Union with innovations and expansion of different systems, as the Codecision system, where the EP and the Council of the EU stand in equal terms in more and more policies. As the European building process has been developed with deeper integration, there has been a growing necessity to link the process with the European people in order to give a democratic approach to the European Union. (Kerikmäe \& Nyman-Metcalf, 2011) The European Parliament is the institutions representing the European people, and hence its power is growing and the power of the Council of the $\mathrm{EU}$ is decreasing at the same time.

The future of the Council of the EU does not look like bright in this process which is weakening the institution treaty after treaty, and hence it might become and empty institution with very limited power unless a big reform in the institutional framework of the European Union is done establishing new competences to the current institutions. (Gnesotto \& Grevi, 2006)

\section{CONCLUSIONS}

The European Council, the representation of the head of the governments of the member states of the European Union, is the political leader of the Union and it is an institution called to become the leading forcer inside the EU. Traditionally it played a more modest role directing the integration from the darkness of secret agreements between governments without any voting system, working through consensus, 
agreements between gentlemen. It was in reality holding the power but letting other European institution to represent its interest, the Council of the EU. Currently the European Union is needed of a stronger political leadership, as the integration is opening to political fields, before just in the hands of the national states.

On the other hand, the Council of the EU is reducing its muscle in the European Institutions as the necessity of democracy is improving the powers of the European Parliament. The subordination to the European Council, the subordination of the national ministers to the head of their national governments, is clear, but has not been plainly established in the European Union. It is mainly a consequence of the view of some member states of the European Union as an intergovernmental organization without any integration in real political matters and focus on economic issues, and hence there was no necessity to involved politics in the European institutions, just the ministers in order to negotiate the technical questions of elaborating common rules for economical transactions between economic agents of the member states. (Krugman, Obstfeld, \& Melitz, 2011)

The recent changes in the Union and the most probably new changes expected in the coming years are developing the Union closer to a political structure with important involvement of areas strongly link with the popular sovereignty. In other words, European Union is becoming more political and hence should have more political control from the member states in order to provide democratic legitimacy to the whole process. (Glenn \& Gordon, 2007)

Taking into consideration the already existing links between both Councils, the necessities of both institutions and the future development of the European Union, the most logical reform to secure this fundamental institution in the European Union will be the formal merge of the Council of the EU and the European Council. The creation of a single institution, with the formal heads of the state leading it, and the ministers working formally under their command will clarify the institutional framework of the Union, and will help to establish strong borders between different institutions. It will recognize who really holds the power in the Councils, and will make more powerful the situation of the Council of the European Union, currently under a strong pressure. Uniting both institutions will make stronger the voice of the member states in the $\mathrm{EU}$, the intergovernmental side of the EU. In the coming years a balance between intergovernmentalism and federalism (Neal \& Barbezat, 1998) will be require in order to adapt the European Union to the international and domestic challenges and necessities it is facing, and will face.

Europe cannot be built at once, and because if that it really needs the positive involvement of as many political, economic and actors as possible. A strong single Council will balance the power of a growing European Parliament, which sometimes tries to go ahead of the will of the European people. This equilibrium between options, between priorities, between necessities can be achieved just through negotiations and agreements satisfying the actors involved in the process. The best way to obtain it is providing the actors with strong forums or vehicles where to develop their positions and launch the negotiations, providing the actors involved with strong institutions. Hence, the creation of a single Council is an essential step for the good working of the European Union for the coming years.

\section{WORKS CITED}

Ahearne, A., Pisani-Ferry, J., Sapir, A., \& Véron, N. (2006, 11 30). Global Governance: An Agenda for Europe. Retrieved 11 11, 2013, from Bruegel: http://www.bruegel.org/download/parent/37global-governance-an-agenda-for-europe/file/393-global-governance-an-agenda-for-europeenglish/

Anon. (2008, 09 26). Working groups of the Council of the European Union. Retrieved from Justiitsministeerium: http://www.just.ee/7741

Anon. (2009, 12 30). The High Representative of the Union for Foreign Affairs and Security Policy. Retrieved from Europa Summaries of EU legislation: 
http://europa.eu/legislation_summaries/institutional_affairs/treaties/lisbon_treaty/ai0009_en.ht $\mathrm{m}$

Anon. (2013). Presidency websites. Retrieved from Council of the European union: http://www.consilium.europa.eu/council/presidency-websites?lang=en

Anon. (2013). The institution. Retrieved from European Council: http://www.europeancouncil.europa.eu/home-page.aspx.

Anon. (n.d.). Council. Retrieved from Council of the European union: http://www.consilium.europa.eu/council?lang=en

Anon. (n.d.). Hierarchic view. Retrieved from EU Whoiswho: http://europa.eu/whoiswho/public/index.cfm?fuseaction=idea. hierarchy\&nodeid=4553

Anon. (n.d.). Hierarchic view. Retrieved from EU Whoiswho: http://europa.eu/whoiswho/public/index.cfm?fuseaction=idea. hierarchy\&nodeid=3760

Anon. (n.d.). The Common Foreign and Security Policy (CFSP). Retrieved from Council of the European union: http://www.consilium.europa.eu/policies/foreign-policy?lang=en

Costa-Font, J. (2012). Europe and the Mediterranean Economy. New York: Routledge Studies in the European Economy. Retrieved from http://www.ewidgetsonline.net/dxreader/Reader.aspx?token=5d1b7bb4102a4c5c8e3fbe5b7b0 3c2f7\&rand $=24738693 \&$ buyNowLink $=\&$ page $=\&$ chapter $=$

Crafts, N. (2008, 07 11). Want faster European Growth? Learn to love creative destruction. Retrieved 11 11, 2013, from VoxEU: http://www.voxeu.org/article/want-faster-european-growth-learnlove-creative-destruction

Elgström, O. (2004). European Union Council Presidencies: A Comparative Analysis. London: Routledge Advances in European Politics. Retrieved from http://books.google.rs/books?id=0_4pvpSEm_cC\&printsec=frontcover\#v=onepage\&q\&f=false

EU. (2007, 09 13). The Council of the European Union. Retrieved from Europa - Summaries of EU legislation:

http://europa.eu/legislation_summaries/institutional_affairs/treaties/nice_treaty/nice_treaty_co uncil_en.htm

Europa. (2007, 09 13). Qualified majority voting. Retrieved from Europa - Summaries of EU legislation: http://europa.eu/legislation_summaries/institutional_affairs/treaties/nice_treaty/nice_treaty_ma jority_en.htm

Glenn, J. C., \& Gordon, T. J. (2007). 2007 State of the Future. Status and future global challenges, The Millennium Project. New York: World Federation of UN Associations. Retrieved from http://www.millennium-project.org/millennium/sof2007.html

Gnesotto, N., \& Grevi, G. (2006). The New GlobalPuzzle, What for the EU in 2025?, European Union Institute for Security Studies. Retrieved from Institute for Security Studies: http://www.iss.europa.eu/uploads/media/NGP_01.pdf

Grahn, R. (2009, 12 10). EU Council Secretary-General Pierre de Boissieu. Retrieved from Grahnlaw: http://grahnlaw.blogspot.com/search/label/General\%20Secretariat

Kant, I. (2005). Perpetual Peace. New York: Cosimo Inc. Retrieved from http://www.amazon.com/Perpetual-Peace-ImmanuelKant/dp/1596055499\#reader_1596055499

Kerikmäe, T., \& Nyman-Metcalf, K. (2011). EU standards and deliberative democracy: Case of Kyrgyzstan. L'Europe unie/United Europe(5), 38-51.

Krugman, P. R., Obstfeld, M., \& Melitz, M. (2011). International Economics (9th Edition). Prentice Hall.

Levitt, M. S., \& Lord, C. (2000). The Political Economy of Monetary Union, (The European Union Series). New York: St. Martin's Press.

McKay, D. (1999). Federalism and European Union: A Political Economy Perspective. Oxford: Oxford University press. 
Neal, L., \& Barbezat, D. (1998). The Economics of the European Union and the Economies of Europe. Oxford, USA: Oxford University Press.

Pisani-Ferry, J. (2005). Speeding up European Reform: A Master Plan for the LisbonProcess. Retrieved from IDEAS.

President of the European Council. (2009, 09). Background. Retrieved from General Secretariat of the Council of the EU: http://www.consilium.europa.eu/uedocs/cms_data/docs/pressdata/en/ec/111298.pdf

Ramiro Troitino, D. (2013). European Integration, building Europe. Nova science Publishers.

Rodríguez-Pose, A. (2002). The European Union: Economy, Society, and Politics. Oxford: Oxford University Press.

Staab, A. (2013). The European Union Explained: Institutions, Actors, Global Impact. Bloomington: Indiana University Press. Retrieved from http://books.google.rs/books?id=qNNnYC8eo8C \& printsec=frontcover\&dq=Staab, + Andreas $+\% 282013 \% 29 .+$ The + European + Union + Expl ained:+Institutions, + Actors, + Global+Impact, + Indiana+University+Press.\&hl=en\&sa=X\&ei=gHi 1 UrWNKY-thQe4ioGYDA\&ved=0CDUQ6AEwAA\#v=onepage\& $=S t$

Tsoukalis, L. (2008). Thoughts on Governance and Power in the World. Brusseles: European Commission European Research Area. Retrieved 11 11, 2013, from http://www.loukastsoukalis.gr/?lang=en; http://www.slideshare.net/PO/the-world-in-2025rising-asia-and-socioecological-transition

Received for publication: $\quad 23.10 .2013$

Revision received: $\quad 20.12 .2013$

Accepted for publication: $\quad 21.12 .2013$

\section{How to cite this article?}

Style - APA Sixth Edition:

Ramiro Troitino, D. (2014, 01 15). The European Council and the Council of the EU - past, present and future. (Z. Čekerevac, Ed.) MEST Journal, 2(1), 7-17. doi:10.12709/mest.02.02.01.02

Stile - Chicago Fifteenth Edition

Ramiro Troitino, David. "The European Council and the Council of the EU - past, present and future." Edited by Zoran Čekerevac. MEST Journal (MESTE) 2, no. 1 (01 2014): 7-17.

Style - GOST Name Sort:

Ramiro Troitino David The European Council and the Council of the EU - past, present and future [Journal] // MEST Journal / ed. Čekerevac Zoran. - Belgrade : MESTE, 01 15, 2014. - 1 : Vol. 2. - pp. 7-17. - ISSN 2334-7058 (Online); ISSN 2334-7171.

Style - Harvard Anglia:

Ramiro Troitino, D., 2014. The European Council and the Council of the EU - past, present and future. MEST Journal, 15 01, 2(1), pp. 7-17.

Style - ISO 690 Numerical Reference:

The correlation-regression models usage as a way to increase of labor productivity. Shkola, Ihor and Petraschak, Oksana. [ed.] Zoran Čekerevac. 1, Belgrade : MESTE, 01 15, 2014, MEST Journal, Vol. 2, pp. 1-6. ISSN 2334-7058 (Online); ISSN 2334-7171. 